https://doi.org/10.5719/aub-g/68.1/3

\title{
THE TOURIST POTENTIAL OF LOCALITIES WITH MINERAL WATER SOURCES IN BRAŞOV COUNTY
}

\author{
RODICA LUPU ${ }^{1}$, LILIANA ZAHARIA ${ }^{2}$
}

\begin{abstract}
This paper aims to assess the tourist potential of the localities with mineral water sources in Brassov County, in order to identify the areas with a high potential for the development of spa tourism. The paper is based on the synthesis of the information obtained from scientific papers, archive documents and field investigations from 2011-2016. In order to rank the localities in terms of tourism potential, two evaluation sheets were used in which different scores have been awarded: 1) the sheet based on the criteria proposed at national level in the Methodology for the analysis of the tourism potential of the territory; 2) a sheet with our own criteria regarding the spa potential of the analysed localities. Based on the obtained scores, three areas with potential for development of the spa tourism were distinguished within Brașov County: 1) the Făgăraş area, with the localities Rodbav/Băile Rodbav, Perşani/Băile Perşani, Grid and Veneția de Jos (with a total of 186.27 points); 2) Brașov municipality, which includes the localities Măieruş, Codlea, Zizin and Târlungeni (with 163.86 points) and 3) Rupea area, including Rupea, Homorod/Băile Homorod, Mercheaşa and Jimbor (with a total of 159.62 points).
\end{abstract}

Keywords: mineral waters, tourism potential, spa tourism, Brașov County.

\section{Introduction}

The socio-economic development of a region or settlement requires the capitalization of the full potential (natural and anthropic) of the region or locality (Cândea et al., 2003). An activity that can play a significant role in the economic development of a territory is tourism. This paper aims to investigate the tourist potential of the settlements with mineral water sources in Braşov County and to achieve their hierarchy in order to identify the localities and areas with a high potential for the development of the spa tourism. The evaluation is based on a set of criteria that include both components that define tourism potential and other complementary elements that favour its valorisation (specific tourism infrastructure, technical infrastructure, etc.).

Secondary School No. 19, Brașov, Romania, < kanord2908@yahoo.com >

2 University of Bucharest, Faculty of Geography, 1, Nicolae Balcescu, Sector 1, 010074, Bucharest, Romania, <zaharialili@hotmail.com > 
In Braşov County, 19 localities with mineral water sources were identified based on the information from the literature and the field investigations during the period 2011-2016 (Fig. 1). The localities can be grouped in 5 areas, in which the mineral waters have similar physico-chemical parameters (Mereț, 2017): 1) Rupea-Homorod-Racoș area; 2) Șinca-Perşani-Veneția de Jos area; 3) TârlungeniZizin-Predeal area; 4) Codlea-Măieruş area; 5) isolated localities (Rodbav and Bran). In this paper, only 13 localities with mineral water sources were considered, eliminating those where mineral springs have a low discharge (Săcele), are intermittent (Bran) or dried (Predeal, Dacia, Șinca and Părău).

The paper provides new information on the spa tourism potential in Brașov County and is based on an original methodology, which has allowed the identification of localities and areas with a high potential for the development of spa tourism, which could contribute to the "revitalization" of this type of tourism in Brașov County.

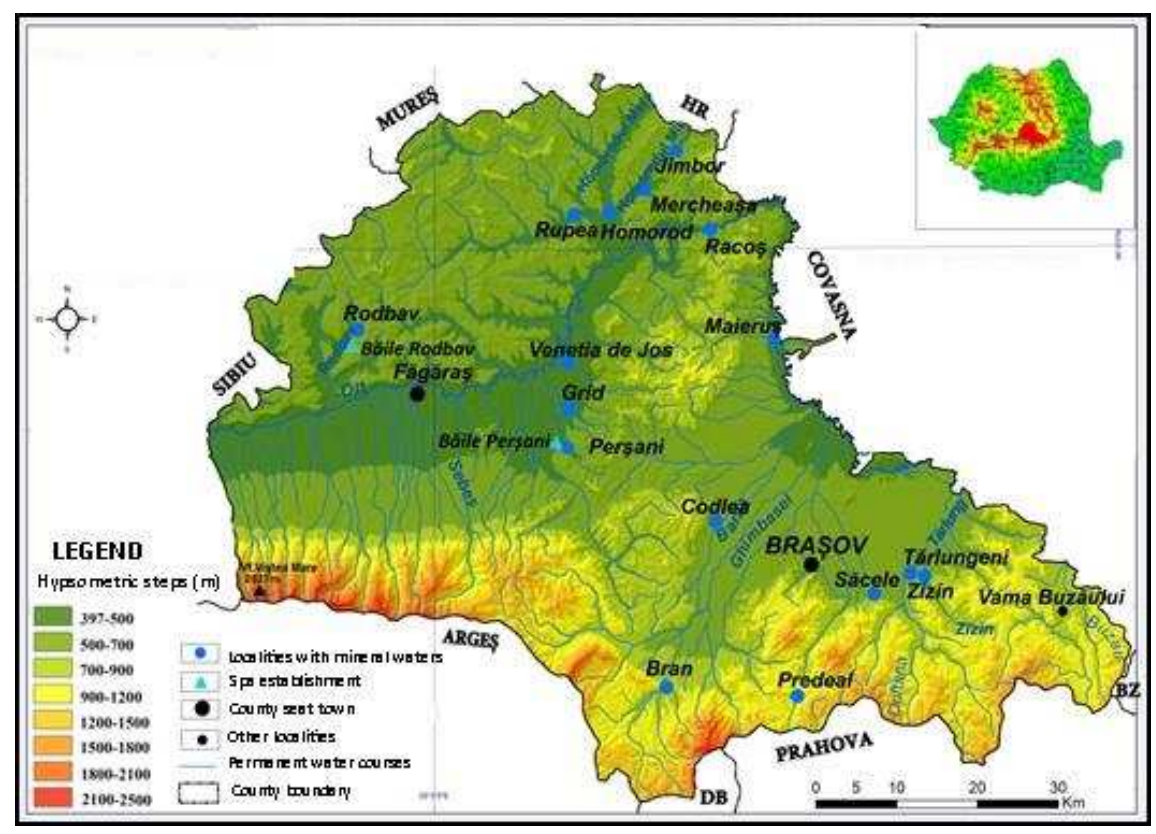

Fig. 1. Location of the settlements with mineral waters in Brașov County

\section{Data and methods}

Four main types of data were used for this work: 1) synthesized information from scientific papers and cartographic documents (eg. List of historical monuments in Brașov County, 2015; List of natural reserves in Brașov County, 2000); 
2) information obtained from archive documents (monographs, minutes, photos, etc.);

3) information extracted and processed from on-line databases (e.g., climatic data);

4) information obtained from field investigations during 2011-2016 (interviews with representatives of local authorities and local people; observations on mineral water sources, their state and mode of exploitation; inventory of natural and anthropic tourist objectives). Graphic and cartographic representations were made using specific techniques and softs (Arc GIS 10.1, Global Mapper 12, Arc Map, Photo Impact and Excel).

The assessment of tourism potential was based on the use of two sheets: 1) a sheet based on the criteria proposed at national level in The methodology for the analysis of the tourism potential of the territory (with Annexes $A$ and $B$ ) at the level of the basic administrative-territorial units (ATUs) elaborated in 2016 by the Ministry of Regional Development and Public Administration in collaboration with the Ministry of Economy, Commerce and Business Environment Relations, and 2) an own criteria sheet regarding the spa potential of the analysed localities. By adding the scores to the criteria in the two sheets, at the level of the localities we obtained a total score for each sheet. In order to obtain the final score for a locality, we calculated the weighted average, the score in the sheet based on the national methodology having a weight of $75 \%$ and the one in the sheet with our own criteria, $25 \%$. Depending on the scores obtained, the analysed localities were hierarchized according to the classification proposed by Ciangă (1988), which distinguished 6 groups as follows: group I (over 60 points), group II (50-60 points), group III (40-50 punches); group IV (30-40 points); group V(20-30 points) and group VI (less than 20 points).

\section{Tourism potential estimated based on the national methodology}

According to The methodology for the analysis of the tourism potential of the territory (2016) elaborated at national level, the assessment of the tourist potential of the administrative-territorial units is based on criteria and subcriteria classified into four major categories: natural tourism resources (A), anthropic tourism resources (B), specific tourist infrastructure (C) and technical infrastructure (D).

\subsection{Natural tourism resources}

The natural tourism resources are assessed on the basis of three major components: natural environment (A1), natural therapeutic factors (A2) and protected natural areas (A3), each of which includes other subcategories/components (geographical position, vegetation, hydrography, nature reserves, etc). The scores obtained at the criterion of the natural resources are relatively close (11-17 points). The maximum 
score given to the criterion A is 25 points (p). Most points were obtained by the localities, Perşani/Băile Perșani (17 p), Racoş (16 p), Rupea (16 p) and Rodbav/ Băile Rodbav (16 p) (Table 1). The higher score obtained by these locations is determined by the existence of some protected areas of particular importance in the area such as "The basalt columns" of Racoș, or the "muddy volcanoes" from Homorod/Băile Homorod, etc. The smallest score on this criterion was obtained by Jimbor ( 8 p) (Table 1).

Table 1

Assessment of the tourist potential of the localities with mineral water sources based on the national methodology for analyzing the tourist potential of the territory

\begin{tabular}{|c|c|c|c|c|c|c|c|c|c|c|c|c|c|c|c|c|c|c|c|c|c|c|}
\hline \multirow{2}{*}{ No. } & \multirow{2}{*}{ Settlement } & \multicolumn{4}{|c|}{$\begin{array}{l}\text { A. Natural tourism resources } \\
\text { (Maximum 25p) }\end{array}$} & \multicolumn{6}{|c|}{$\begin{array}{l}\text { B. Anthropic tourism resources } \\
\text { (Maximum 25p) }\end{array}$} & \multicolumn{6}{|c|}{$\begin{array}{l}\text { C. Specific tourist infrastructure } \\
\text { (Maximum 20p) }\end{array}$} & \multicolumn{4}{|c|}{$\begin{array}{l}\text { D. Technical infrastructure } \\
\text { (Maximum 30p) }\end{array}$} & \multirow[t]{2}{*}{$\begin{array}{l}\text { Total } \\
\text { score }\end{array}$} \\
\hline & & $\begin{array}{c}A_{1} \\
(10 \mathrm{p})\end{array}$ & $\begin{array}{c}A_{2} \\
(10 p)\end{array}$ & $\begin{array}{c}A_{5} \\
(5 p)\end{array}$ & Tot & $\begin{array}{c}B_{1} \\
(8 p)\end{array}$ & $B_{2}(9 p)$ & $\begin{array}{c}B_{3} \\
(8 / 4 \mathrm{p})\end{array}$ & $\begin{array}{c}B_{4} \\
(8 / 4 p)\end{array}$ & $\begin{array}{r}B_{5} \\
(0 / 4 p)\end{array}$ & Tot & $\begin{array}{c}c_{1} \\
(7 p)\end{array}$ & $\begin{array}{c}c_{2} \\
(5 p)\end{array}$ & $\begin{array}{c}c_{3} \\
(6 p)\end{array}$ & $\begin{array}{c}c_{4} \\
(12 p)\end{array}$ & $\begin{array}{c}c_{5} \\
(1 p)\end{array}$ & Tot & \begin{tabular}{|c|} 
\\
$D_{1}$ \\
$(10 \mathrm{pp})$ \\
\end{tabular} & $\begin{array}{c}D_{2} \\
(10 \mathrm{p})\end{array}$ & $\begin{array}{c}D_{3} \\
(10 \mathrm{pp}) \\
\end{array}$ & Tot & \\
\hline 1 & Rupea & 6 & 5 & 5 & 16 & 8 & 7 & 8 & . & & 23 & 2 & . & . & & - & 2 & 5 & 9 & 5 & 19 & 60 \\
\hline 2 & $\begin{array}{l}\text { Băile } \\
\text { Homorod } \\
\end{array}$ & 5 & 7 & 5 & 17 & 4 & - & 4 & - & 4 & 12 & - & - & - & - & - & 0 & 2 & 5 & 2.5 & 9.5 & 38.5 \\
\hline 3 & Mercheaşa & 5.5 & 3 & 3 & 11.5 & 4 & - & 4 & - & 4 & 12 & - & . & - & - & - & 0 & 1 & 5 & 2.5 & 8.5 & 32 \\
\hline 4 & Jimbor & 5 & 3 & - & 8 & 4 & . & 4 & - & 4 & 12 & . & . & . & - & . & 0 & 1 & 5 & 1 & 7 & 27 \\
\hline 5 & Racos & 8 & 3 & 5 & 16 & 8 & 3 & 4 & - & 4 & 19 & - & - & - & - & - & 0 & 1 & 5 & 2.5 & 8.5 & 43.5 \\
\hline 6 & \begin{tabular}{|l|l|}
$\begin{array}{l}\text { Bäile } \\
\text { Perşani }\end{array}$ \\
\end{tabular} & 6 & 7.5 & 3.5 & 17 & 4 & - & 4 & - & 4 & 12 & 4.25 & 1.5 & - & - & 0.5 & $\begin{array}{c}6.2 \\
5 \\
\end{array}$ & 5 & 5 & 2.5 & 12.5 & 64.75 \\
\hline 7 & Grid & 5 & 7 & - & 12 & . & . & 4 & . & 4 & 8 & 1 & . & . & . & . & 1 & 1 & 5 & 1 & 7 & 28 \\
\hline 8 & \begin{tabular}{|l|}
$\begin{array}{l}\text { Veneția de } \\
\text { Jos }\end{array}$ \\
\end{tabular} & 6 & 4.5 & 3 & 13.5 & 4 & . & 4 & - & 4 & 12 & . & - & - & - & - & 0 & 1 & 5 & 1 & 7 & 32.5 \\
\hline 9 & Zizin & 5.5 & 5 & 2.5 & 13 & 6 & 3 & 4 & - & 4 & 17 & 1 & . & - & - & - & 1 & 1 & 5 & 3 & 9 & 40 \\
\hline 10 & Tărlungeni & 5.5 & 5 & 1 & 11.5 & 4 & - & 4 & - & 4 & 12 & 1 & . & 2 & - & - & 3 & 1 & 5 & 3 & 9 & 35.5 \\
\hline 11 & Codlea & 6.5 & 3 & 5 & 14.5 & 8 & 4 & 4 & 2 & 4 & 22 & - & - & 2 & - & - & 2 & 5 & 9 & 5 & 19 & 57.5 \\
\hline 12 & Mãierus & 5 & 3 & 5 & 13 & 4 & - & 4 & - & 4 & 12 & - & . & - & - & - & 0 & 5 & 5 & 3.5 & 13.5 & 38.5 \\
\hline 13 & $\begin{array}{l}\text { Bäile } \\
\text { Rodbav }\end{array}$ & 5 & 7.5 & 3.5 & 16 & 4 & - & 4 & - & 4 & 12 & 7 & 3.25 & 2 & - & 1 & $\begin{array}{l}13 . \\
25 \\
\end{array}$ & 1 & 5 & 3.5 & 9.5 & 50.75 \\
\hline
\end{tabular}

A1 - Natural environment; A2 - Natural therapeutic factors; A3 - Protected natural areas;

B1 - Historical monuments; B2 - Museums, collections; B3 - Art and folk tradition; B4 - Performing/show institutions; B5 - Repeatable cultural events; C1 - Accommodation units; C2 - Treatment institutions/facilities; C3 - Conference rooms; C4 - Ski slopes;

C5 - Other recreational facilities; D1 - Direct access to major transport infrastructure; D2 - Edilitary infrastructure; D3 - Telecommunications.

On the sub-criterion concerning the potential of the natural environment (A1), the score obtained by the most analysed localities is generally 5-6 points out of the total of 10 allocated points (Table 1). The highest scores were reached by the localities of Racoss $(8 \mathrm{p})$ and Codlea $(6.5 \mathrm{p})$. The scoring difference is given by certain geomorphological aspects that characterize the respective locations (the presence of gorges, caves, the vicinity of some imposing landscapes) and are of interest for tourists (eg. the Olt River gorge from Racoş, Comana Cave, etc.).

For the sub-criterion on natural therapeutic factors (A2), which takes into account mineral water springs, bioclimate and therapeutic mud, the score 
obtained by most of the analyzed localities was over 5 points out of the total of 10 allocated points. Rodbav/Băile Rodbav and Perşani/Băile Perşani obtained 7.5 points, while Homorod/Băile Homorod and Grid scored 7 points. Five points were awarded to Rupea, Zizin and Târlungeni, while for Veneția de Jos the score was 4.5 points. For the other localities the score was under 3 points. At the last sub-criterion of natural tourism resources, namely protected natural areas (A3), Racoş, Homorod/Băile Homorod, Rupea, Codlea and Măieruş obtained the maximum score (5 p), and Grid and Jimbor did not get any points. For Homorod/Băile Homorod, the mineral springs are a reserve of great scientific importance ("muddy volcanoes"). For Racoș, the geological reserves "Basalt columns" and "Racoșu de Jos Geological Complex" are worth mentioning, while in Zizin, the palaeontological reservation from Purcăreni (List of Natural Reserves in Braşov County, 2000) is of interest.

\subsection{Anthropic tourism resources}

According to The methodology for the analysis of the tourism potential of the territory (2016), the anthropic tourism resources comprise several sub-criteria (Historical monuments of national interest - B1; Museums and public collections - B2; Art and folk tradition - B3; Shows and concerts - B4; Repeatable cultural events - B5; UNESCO Monuments - B6), the maximum score being 25 points. The localities with mineral waters in Brassov county with the highest scores are Rupea (23 p), Codlea (22 p) and Racoș (19 p), which have historical/cultural tourism attractions of national importance (archaeological sites, medieval fortresses, fortified churches, memorial houses, etc.), and museums of local importance. For the city of Rupea, we mention the archaeological sites „Pădurea lui Grigore” („Grigoriwald”), „Valea Florilor” („Blumenthal”), the roman salines from the "Rupea Fortress" site ("Cetatea Cohalmului"), the evangelical church ensemble, etc. (List of historical monuments in Brașov County, 2015).

In Codlea, there are some important historical attractions such as: the "Măgura Codlei" archaeological site, the fortified Dacian settlement, the medieval fortification, the Codlea Traditions Museum. Another area with historical objectives is represented by the village of Racoș, with the ensemble of the reformed church, the Sükösd - Bethlen Castle Ensemble, objects listed on The List of Historical Monuments in Brașov County (2015). A component valid and repeatable for the localities with mineral water sources, is represented by the customs, folk traditions, celebrations, social soirees, other specific manifestations. For this component all locations received 4 points. The lowest score for the anthropic tourist resource criterion was obtained by the village of Grid (8 p.). No locality with mineral water sources in the county has monuments included in the UNESCO list (B6) and, as a result, this criterion was not included in the table (Table 1). 


\subsection{Specific tourist infrastructure}

For this criterion, the better represented in the analysed localities are the components: accommodation units/spaces $(\mathrm{C} 1)$, treatment facilities $(\mathrm{C} 2)$ and conference rooms, exhibition centres $(\mathrm{C} 3)$. The score obtained by the analysed localities is low (less than 5 points), because the specific tourist facilities are missing in most localities. Exceptions are made by Perşani/Băile Perşani, where the natural therapeutic factors are exploited "experimentally" and Rodbav/Băile Rodbav, where the modernization works started in order to reintroduce the location in the touristic circuit (Feasibility Study..., 2005). Băile Rodbav have a total of 13, 25 points, and the Băile Perşani 7 points out of the total of 20 points allocated to this criterion (Table 1).

For the sub-criterion on accommodation units (C1), the only settlements with mineral sources in Brassov County that have accommodation facilities for harnessing the therapeutic potential are Rodbav/Băile Rodbav (which obtained the maximum of 7 points allocated to this sub-criterion) and Perșani/Băile Perşani (which obtained 4,25 p). There are tourist pensions in Rupea ( $2 \mathrm{p}$ ), Codlea ( 2 p), Zizin (1 p), Târlungeni (1 p), Grid (1 p), but they are used to exploit the particularities of the natural environment or the anthropic touristic potential not the therapeutic one.

The treatment facility sub-criterion (C2) was applied only to Perşani/Băile Perşani and Rodbav/Băile Rodbav (2.5 p and 3.25 p respectively). A small conference room is located at Băile Rodbav, within the Complex ( 2 p). For Târlungeni we can mention the "Perla Ciucaşului" Hotel, which also has a conference room $(2 \mathrm{p})$.

\subsection{Technical infrastructure}

The transport and edilitary infrastructure (sewerage, natural gas supply, etc.) and telecommunications play an important role in capitalizing on the tourist potential of a settlement. As a result, the maximum score, according to The methodology for the analysis of the tourism potential of the territory (2016), is the highest ( $30 \mathrm{p})$.

The localities that obtained the highest score for this criterion were Rupea (19 p), Codlea (19 p), Perşani / Băile Perșani (15 p) and Măieruş (13.5 p). The lowest score (7 points) was recorded by the following localities: Jimbor, Grid and Veneția de Jos (Table 1). A particularly advantageous location with direct access to the major transport infrastructure (European road / national road / railway) has Perşani / Băile Perşani, Rupea and Codlea, each obtaining 5 points. The other locations have access to county roads, generally in good state. Rodbav / Băile Rodbav, although have access to county roads DJ 105 A and DJ 104 D, 
both are in a deteriorated state (in 2016). Farther away from the county road that crosses the village, there are the mineral water springs in Veneția de Jos. The studied localities are supplied with natural gas $(4 \mathrm{p})$, but at the sub-criterion water supply / sewage of pluvial and sewage waters, in some locations (Grid, Mercheaşa, etc.) there are still major deficiencies. The maximum score was obtained by Rupea and Codlea (9 p). In some localities (Grid, Jimbor, Mercheaşa) sewer networks are precarious. In most of the analysed localities, the telecommunication services are of good quality. The situation is favoured by the fact that most of localities have administrative rank, as town / city for Rupea and Codlea or commune residence for Homorod, Târlungeni, Măieruş and Racoş. Without landline telephony, but with GSM coverage, the localities of Mercheasa, Jimbor and Grid are somewhat more remote from the commune residence they belong to. It is worth mentioning the situation of Băile Rodbav, which is slightly isolated from the village where it belongs (Rodbav) and the commune residence (Şoarş), which is supplied with natural gas, water, electricity and optical fiber for telecommunication services.

\section{The spa tourism potential assessed on the basis of own criteria}

In order to assess the spa tourism potential, a sheet with our own criteria and scores was used for the following components: mineral water springs (number, degree of mineralization, spa importance), therapeutic mud, bioclimate type, existing facilities and accessibility) (Table 2). Following these criteria, the localities that obtained the highest score were Rodbav / Băile Rodbav (71.5 p) and Perşani / Băile Perşani (54.5 p), and the lowest was registered by Măieruş $(14 \mathrm{p})$. Four settlements were scored between 40 and 50 points (Rupea, Veneția de Jos, Zizin and Târlungeni) (Table 2). With a score of 20 to 30 points there are 3 localities (Racoş, Mercheaşa and Jimbor), which do not have special facilities, but the therapeutic properties of mineral waters indicate them to be used in rheumatic diseases. To this is added Codlea ( $28 \mathrm{p})$, where it is remarkable the leisure complex frequented during the summer (Table 2).

On the criterion of mineral water springs (number, degree of mineralization), the localities that obtained the highest score are Rodbav / Băile Rodbav (26 p) and Veneția de Jos (17 p), which have a larger number of springs ( 7 springs in Veneția de Jos and 8 springs at Rodbav / Băile Rodbav) and the degree of mineralization of water is higher. The lowest score (5 points) was obtained by Măieruş (one source, poorly mineralized). For Racoş (17 p), Mercheașa (12 p), Grid (12 p) and Jimbor (12 p), although there are few sources, the water is highly mineralized (e.g. at Mercheaşa, the content of chlorine is $180,881.2 \mathrm{mg} / \mathrm{l}$ ) (Mereţ, 2017). 
For the mud treatment criterion, the localities Perşani / Băile Perşani, with sapropelic mud (Munteanu and Dumitraşcu, 2011), Grid (Mereţ et al., 2017), Rodbav / Băile Rodbav and Homorod / Băile Homorod with mineral mud (Munteanu and Dumitraşcu, 2011) received 10 points (Fig. 2a, b). For Rupea, the location where this resource was identified based on field observations (Fig. 2c), 5 points were awarded.

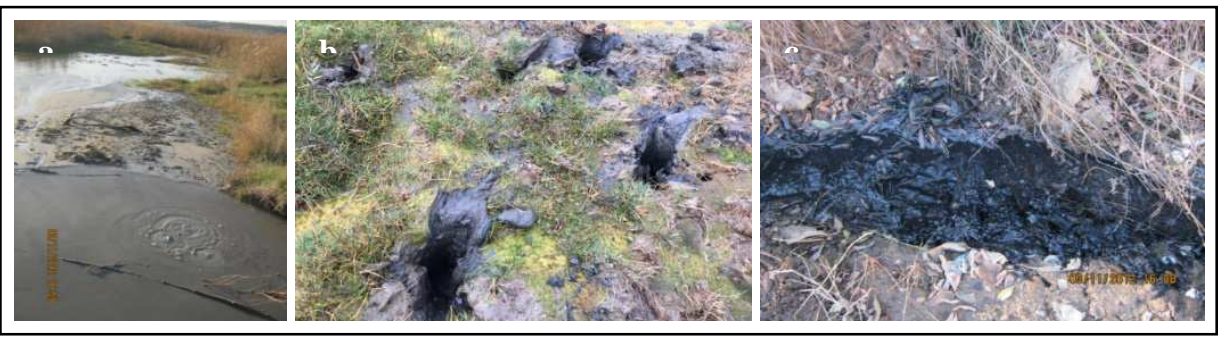

Fig. 2. Therapeutic mud in Brașov county at: a - Homorod / Băile Homorod; b - Grid; c - Rupea (Author: Mereţ, 2012-2016)

Table 2

Assessment of the spa potential of the localities with mineral water sources in Braşov County based on the own criteria

\begin{tabular}{|c|c|c|c|c|c|c|c|c|c|c|c|c|c|c|c|c|}
\hline \multirow[b]{2}{*}{ No. } & \multirow[b]{2}{*}{ Settlement } & \multirow{2}{*}{$\begin{array}{c}\text { Number } \\
\text { of } \\
\text { mineral } \\
\text { sources } \\
\text { (20p) }\end{array}$} & \multicolumn{3}{|c|}{ Mineralization } & \multirow[b]{2}{*}{$\begin{array}{l}\text { Mud } \\
\text { (10p) }\end{array}$} & \multicolumn{3}{|c|}{ Spa importance (25p) } & \multicolumn{2}{|c|}{ Facilities (10p) } & \multicolumn{3}{|c|}{ Access (10p) } & \multirow[b]{2}{*}{$\begin{array}{l}\text { Other } \\
\text { aspects } \\
(5 \text { p) }\end{array}$} & \multirow[b]{2}{*}{$\begin{array}{l}\text { Total } \\
\text { score }\end{array}$} \\
\hline & & & \begin{tabular}{|l|} 
High \\
(10p)
\end{tabular} & $\begin{array}{c}\text { Medium } \\
(\mathrm{pp})\end{array}$ & $\begin{array}{l}\text { Low } \\
\text { (3p) }\end{array}$ & & $\begin{array}{c}\text { Internal } \\
\text { cure (10p) }\end{array}$ & $\begin{array}{l}\text { External } \\
\text { cure (10p) }\end{array}$ & $\begin{array}{c}\text { Bioclimat } \\
\text { (5p) }\end{array}$ & $\begin{array}{l}\text { Bathing } \\
\text { fachlitites } \\
(7 \mathrm{p})\end{array}$ & $\begin{array}{c}\text { Other facilities } \\
(3 \mathrm{p})\end{array}$ & $\begin{array}{l}\text { Direct } \\
(7 \mathrm{p})\end{array}$ & $\begin{array}{l}\text { Medium } \\
(2 p)\end{array}$ & $\begin{array}{l}\text { Difficult } \\
\text { (1p) }\end{array}$ & & \\
\hline 1 & Rupea & $\begin{array}{c}8 \mathrm{p} \\
(4 \mathrm{~s} \times 2 \mathrm{p})\end{array}$ & $10 \mathrm{p}$ & $7 \mathrm{p}$ & - & - & - & 10p & $5 p$ & - & $\begin{array}{c}3 \mathrm{p} \\
\text { (fountain) }\end{array}$ & $7 \mathrm{p}$ & - & - & & 50p \\
\hline 2 & $\begin{array}{l}\text { Baile } \\
\text { Homorod }\end{array}$ & $\begin{array}{c}6 \mathrm{p} \\
(3 \mathrm{sx} 2 \mathrm{p})\end{array}$ & - & $7 \mathrm{p}$ & - & 10p & 10p & 10p & $5 \mathrm{p}$ & - & - & - & $2 \mathrm{p}$ & - & $\begin{array}{c}1 \mathrm{p} \\
\text { (2 pools) }\end{array}$ & $51 \mathrm{p}$ \\
\hline 3 & Mercheașa & $\left.\begin{array}{c}2 \mathrm{p} \\
(1 \mathrm{~s} \times 2 \mathrm{p})\end{array}\right)$ & $10 \mathrm{p}$ & - & - & - & - & $5 p$ & $5 \mathrm{p}$ & $\cdot$ & $\begin{array}{c}1 \mathrm{p} \\
\text { (fountain) }\end{array}$ & - & 20p & - & - & $25 p$ \\
\hline 4 & Jimbor & $\begin{array}{c}2 \mathrm{p} \\
(1 \times 2 \mathrm{p})\end{array}$ & $10 \mathrm{p}$ & - & - & - & - & $5 p$ & $5 \mathrm{p}$ & - & $\begin{array}{c}1 \mathrm{p} \\
\text { (fountain) }\end{array}$ & - & $2 p$ & - & - & $25 \mathrm{p}$ \\
\hline 5 & Racoș & $\begin{array}{c}4 \mathrm{p} \\
(25 \times 2 \mathrm{p})\end{array}$ & $10 \mathrm{p}$ & - & $3 p$ & - & - & $5 p$ & $5 p$ & - & $\begin{array}{c}1 \mathrm{p} \\
\text { (fountain) }\end{array}$ & - & $2 \mathrm{p}$ & - & - & 30p \\
\hline 6 & $\begin{array}{l}\text { Bãile } \\
\text { Perşani }\end{array}$ & $\begin{array}{c}4 \mathrm{p} \\
(25 \times 2 \mathrm{p})\end{array}$ & - & $7 \mathrm{p}$ & - & 10p & - & 10p & $5 \mathrm{p}$ & $3.5 \mathrm{p}$ & $3 p$ & $7 \mathrm{p}$ & $\cdot$ & $\cdot$ & $5 p$ & $54.5 \mathrm{p}$ \\
\hline 7 & Grid & $\begin{array}{c}2 \mathrm{p} \\
(15 \times 2 \mathrm{p})\end{array}$ & $10 \mathrm{p}$ & - & - & 10p & - & $10 \mathrm{p}$ & $5 p$ & - & - & - & - & $1 \mathrm{p}$ & - & $38 \mathrm{p}$ \\
\hline 8 & $\begin{array}{l}\text { Veneția de } \\
\text { Jos }\end{array}$ & $\begin{array}{c}14 p \\
(7 \times 2 p)\end{array}$ & - & $\cdot$ & $3 \mathrm{p}$ & 10p & 10p & $\begin{array}{c}5 \mathrm{p} \\
\text { (mud) }\end{array}$ & $5 p$ & - & - & - & - & Ip & - & $48 \mathrm{p}$ \\
\hline 9 & Zizin & $\begin{array}{c}10 \mathrm{p} \\
(5 \mathrm{~s} \times 2 \mathrm{p})\end{array}$ & - & $\begin{array}{c}7 p \\
(1 s)\end{array}$ & $\begin{array}{l}3 p \\
(1 s)\end{array}$ & - & 10p & $\begin{array}{c}5 \mathrm{p} \\
\text { (water) }\end{array}$ & $4 \mathrm{p}$ & - & - & - & $2 \mathrm{p}$ & - & - & $41 \mathrm{p}$ \\
\hline 10 & Tărlungeni & $\begin{array}{c}10 \mathrm{p} \\
(5 \times 2 \mathrm{p})\end{array}$ & $\cdot$ & $\begin{array}{l}7 p \\
(1 s)\end{array}$ & $\begin{array}{l}3 \mathrm{p} \\
(2 \mathrm{~s})\end{array}$ & $\cdot$ & 10p & $5 \mathrm{p}$ & $4 \mathrm{p}$ & $\cdot$ & $\cdot$ & $\cdot$ & $2 \mathrm{p}$ & - & $\cdot$ & $41 \mathrm{p}$ \\
\hline 11 & Codlea & $\begin{array}{c}6 \mathrm{p} \\
(3 \mathrm{~s} \times 2 \mathrm{p})\end{array}$ & $\cdot$ & - & $3 \mathrm{p}$ & $\cdot$ & - & $5 \mathrm{p}$ & $4 p$ & - & $3 p$ & $\cdot$ & $2 \mathrm{p}$ & - & $5 \mathrm{p}$ & $28 \mathrm{p}$ \\
\hline 12 & Māieruș & $\begin{array}{c}2 \mathrm{p} \\
(1 \mathrm{~s} \times 2 \mathrm{p})\end{array}$ & $\cdot$ & $\cdot$ & $3 \mathrm{p}$ & - & $2 \mathrm{p}$ & - & $5 \mathrm{p}$ & - & - & - & $2 \mathrm{p}$ & - & - & $14 \mathrm{p}$ \\
\hline 13 & $\begin{array}{l}\text { Băile } \\
\text { Rodbav }\end{array}$ & $\begin{array}{c}16 \mathrm{p} \\
(85 \times 2 \mathrm{p})\end{array}$ & . & $\begin{array}{c}7 p \\
(5 s)\end{array}$ & $\begin{array}{l}3 \mathrm{p} \\
(3 \mathrm{~s})\end{array}$ & 10p & 10p & 10p & $5 \mathrm{p}$ & $3.5 \mathrm{p}$ & $3 p$ & - & $2 \mathrm{p}$ & - & $5 p$ & $71.5 \mathrm{p}$ \\
\hline
\end{tabular}

$\mathrm{p}=$ point $; \mathrm{s}=$ source.

Concerning the bioclimates specific to Braşov County, according to the Bioclimatic Atlas of Romania (Ionac and Ciulache, 2008) and the studies performed by the balneology physicians (Dinculescu and Berlescu, 1963; Teodoreanu and al., 1984, etc.), the hilly and depression area (400-800 m) fall 
into sedative - indifferent bioclimate (sparing). The localities with such bioclimate are Perşani / Băile Perşani, Homorod / Băile Homorod and Veneția de Jos. By analogy, Grid and Rupea, close to those above mentioned and for which the climatic parameters analysed indicate similar values, can be considered as falling within the same type of bioclimate (Table 3). For Zizin, the specialists indicated a climate of a tonic-stimulant intra-mountain depression (Dinculescu et al., 1975; Teodoreanu et al., 1984). We believe, however, that there is a shift from the sedative climate - indifferent to the tonic - stimulant (this type of bioclimate being specific to altitudes over 700-800 m). Similarly, Rodbav / Băile Rodbav belong to this type of bioclimate (Berlescu, 1971).

By the characteristics of the climatic parameters (lower temperatures, precipitation over $700 \mathrm{~mm} /$ year, etc.), we also appreciate that Codlea would fall into the stimulating tonic climate. The localities with a sedative - indifferent bioclimate have obtained the maximum score $(5 \mathrm{p})$, and those assigned to the tonic - stimulant bioclimate obtained 4 points (Zizin, Târlungeni and Codlea).

Table 3

The main climatic parameters (multiannual averages) in the localities with mineral water sources in Braşov County, 1961-2013

\begin{tabular}{|c|l|c|c|c|c|c|}
\hline $\begin{array}{c}\text { No. } \\
\text { crt. }\end{array}$ & Location & $\begin{array}{c}\text { T med } \\
\text { year } \\
\left({ }^{\circ} \mathbf{C}\right)\end{array}$ & $\begin{array}{c}\text { Precipitation } \\
(\mathbf{m m} / \mathbf{a n})\end{array}$ & $\begin{array}{c}\text { Sunshine } \\
\text { duration } \\
(\text { no. hours })\end{array}$ & $\begin{array}{c}\text { Nebulosity } \\
(\text { tenths })\end{array}$ & $\begin{array}{c}\text { Relative } \\
\text { humidity } \\
(\boldsymbol{\%})\end{array}$ \\
\hline 1 & Rupea & 8.2 & 624.7 & 2012.6 & 6.2 & 80.0 \\
\hline 2 & Băile Homorod & 8.3 & 588.8 & 2042 & 6.2 & 79.0 \\
\hline 3 & Mercheaşa & 8.1 & 595 & 2039.7 & 6.2 & 77.8 \\
\hline 4 & Jimbor* & 8.1 & 598.2 & - & - & - \\
\hline 5 & Racoş* & 8.3 & 598.7 & - & - & - \\
\hline 6 & Băile Perşani & 8.3 & 610 & 1985 & 6.2 & 80.4 \\
\hline 7 & Grid & 8.3 & 610 & 1987 & 6.2 & 80 \\
\hline 8 & Veneţia de Jos & 8.4 & 607.1 & 2026 & 6.3 & 78.1 \\
\hline 9 & Zizin & 7.4 & 677.1 & 1833 & 6.1 & 79.8 \\
\hline 10 & Tărlungeni* & 7.3 & 651.8 & 1815 & 6.3 & 79.7 \\
\hline 11 & Codlea & 6.9 & 715.5 & 1716 & 6.4 & 82.7 \\
\hline 12 & Măieruş* & 8.2 & 591 & - & - & - \\
\hline 13 & Băile Rodbav & 8.4 & 740.3 & 2075 & 5.7 & 76.0 \\
\hline
\end{tabular}

* For these localities the data obtained were only for temperature and precipitation

Data Source: Dumitrescu and Bîrsan, 2015; https://es.climate-data.org/, period 1981-2013).

$\mathrm{T}$ med $=$ average air temperature

Regarding the treatment / spa facilities criterion, there are small arrangements at Perșani/Băile Perşani (Fig. 3a, b), mainly for leisure and less for balneary purposes (Mereț and Zaharia, 2014). At Rodbav / Băile Rodbav important modernization works of the old spa facility were carried out (Fig. 3c), but the installations are not functional yet (Mereţ, 2013; Feasibility Study..., 2005). Both locations received 6.5 points out of a maximum of 10 points (Table 2). 
At most of the sites analysed, access to mineral water sources is quite easy, except for Veneția de Jos and Grid.

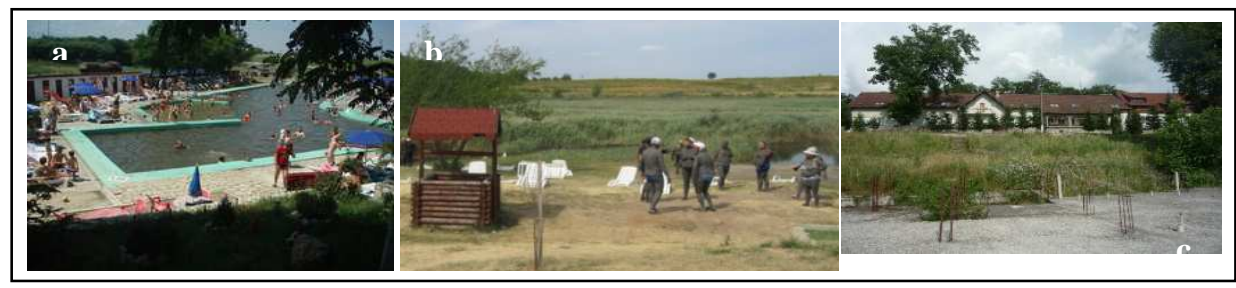

Fig. 3. Spa facilities: a - the pool of Băile Perșani; b - the mud area from Băile Perșani; c - balneary facility at Băile Rodbav

(Author : Mereț and Zaharia, 2013)

\section{Hierarchy of the localities with mineral water sources in Braşov County, in terms of the tourist potential}

Based on the scores obtained by the analysed localities, according to The national methodology for the analysis of the tourist potential of the territory and of our own criteria for evaluation of the spa tourism potential, the general hierarchy of the localities with mineral water sources in Braşov county was carried out, in term of the tourism potential. As mentioned, the final score obtained by each locality is the result of the weighted average of the scores obtained by each locality, by applying the two assessment sheets (Table 1 and Table 2).

Depending on the final scores, the localities were grouped according to the classification proposed by Ciangă (1998), which distinguished six classes from the point of view of the tourist potential of an area or locality. Thus, in the first group (over 60 p), only Perşani / Băile Perşani was ranked, with 62.75 points. The settlement with the lowest score is Jimbor, with 27 points (Group V). In the second group (50-60 p) belonged three localities (Rodbav / Băile Rodbav, Rupea and Codlea) and three localities in the third value group (40-50 p) (Homorod / Băile Homorod, Zizin and Racoș). Five localities were included in the 4th group (30-40 p), namely Târlungeni, Veneția de Jos, Grid, Măieruş and Mercheaşa. No locality had a total score of less than 20 points (Table 4).

Therefore, there is a balanced situation of the localities with mineral water sources in Braşov county, half of them being in the first part of the hierarchy (7 localities). The superior position (1st place) occupied by Perşani / Băile Perşani is justified by the natural tourist potential and the technical infrastructure (direct access of this location, major transport infrastructure, edilitary infrastructure, telecommunication). For Rupea, the top-of-the-list position (16 p) is explained, first and foremost, by the technical infrastructure 
(19 p) and also by its therapeutic potential (Mereț and Zaharia, 2016). Regarding the upper position (III ${ }^{\mathrm{rd}}$ place) of the Codlea in this hierarchy, it is explained by the administrative rank that it has (municipality), and consequently the technical infrastructure is superior, plus the geographical position, also favourable. By summing the scores obtained by the localities with mineral water sources assessed from the point of view of tourist potential (implicit of the spa), several areas with tourism development potential could be distinguished. The highest potential has the area of Făgăraș, which includes the localities Rodbav / Băile Rodbav, Perşani / Băile Perşani, Grid and Veneția de Jos, with a total of 186.27 points. A second area is extended in the vicinity of Brassov municipality, including the villages of Măieruş, Codlea, Zizin and Târlungeni, with 163.86 points. The third area is in the vicinity of Rupea - including the settlements of Rupea, Homorod / Băile Homorod, Mercheașa and Jimbor, with a total of 159.62 points. Although the last area has a significant balneary potential (therapeutic factors), some localities (e.g. Mercheaşa, Jimbor) are deficient in the technical infrastructure and the score based on the national methodology is low. Also, although the physico - chemical characteristics of the Racoş mineral water sources are similar to those of Mercheaşa or Jimbor, the too far distance between these localities led us not to include the score of Racoș in this area.

Table 4

Hierarchy and scores of localities with mineral water sources in Brașov County, according to the national methodology for analyzing the tourism potential and to our own assessment criteria for the spa potential

\begin{tabular}{|c|l|c|c|c|}
\hline $\begin{array}{c}\text { No. } \\
\text { crt. }\end{array}$ & $\begin{array}{c}\text { Locality } \\
\begin{array}{c}\text { Scores based } \\
\text { on the national } \\
\text { methodology } \\
\text { (points) }\end{array}\end{array}$ & $\begin{array}{c}\text { Scores based } \\
\text { on own } \\
\text { methodology } \\
\text { (points) }\end{array}$ & $\begin{array}{c}\text { Total } \\
\text { scores } \\
\text { (points) }\end{array}$ \\
\hline 1. & Perşani/Băile Perşani & 64.5 & 57.5 & 62.75 \\
\hline 2. & Rupea & 60 & 53 & 58.25 \\
\hline 3. & Rodbav/Băile Rodbav & 50.7 & 71.5 & 55.9 \\
\hline 4. & Codlea & 57.5 & 36 & 52.12 \\
\hline 5. & Homorod/Băile Homorod & 38.5 & 55 & 42.62 \\
\hline 6. & Zizin & 40 & 44 & 41 \\
\hline 7. & Racoş & 43.5 & 32 & 40.62 \\
\hline 8. & Tărlungeni & 35.5 & 44 & 37.62 \\
\hline 9. & Veneţia de Jos & 32.5 & 49 & 36.62 \\
\hline 10. & Măieruş & 38.5 & 17 & 33.12 \\
\hline 11. & Mercheaşa & 32 & 31 & 31.75 \\
\hline 12. & Grid & 28 & 40 & 31 \\
\hline 13. & Jimbor & 27 & 27 & 27 \\
\hline
\end{tabular}




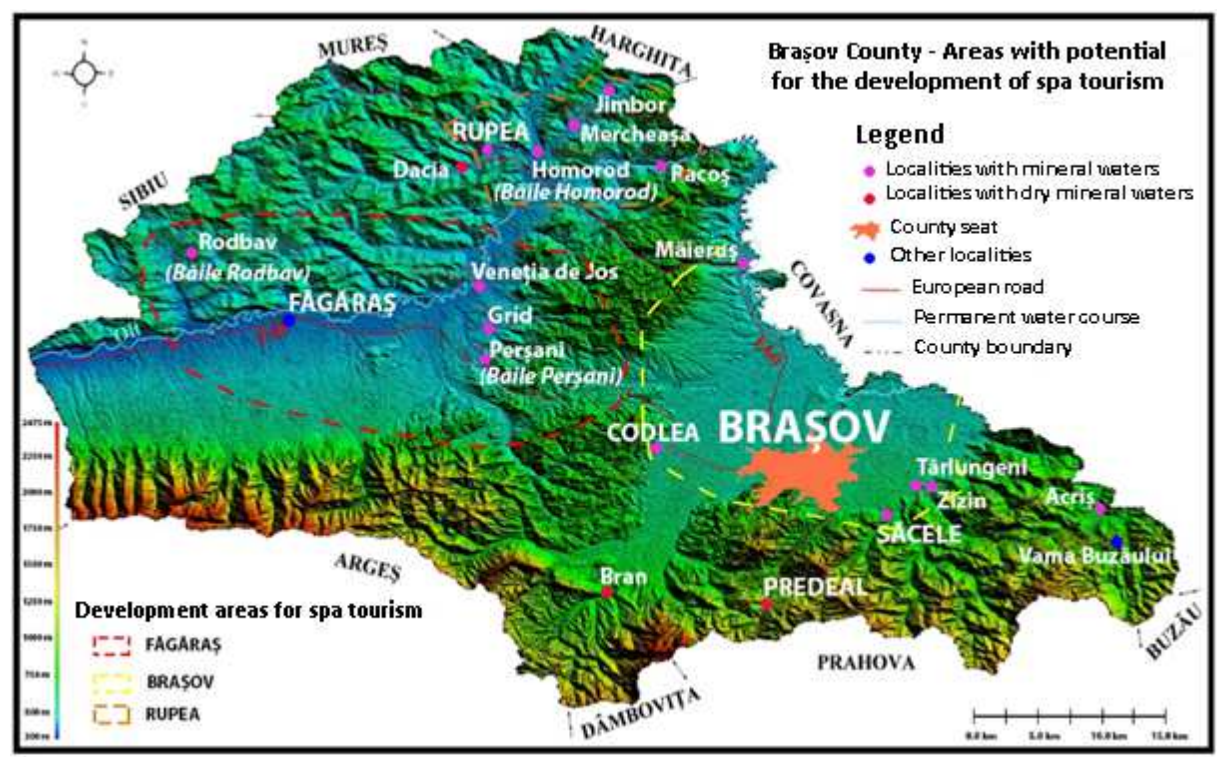

Fig. 4. Localities with mineral waters and areas with potential for development of spa tourism in Brașov County

\section{Conclusions}

The assessment of the tourism potential of the localities with mineral water sources in Braşov County, based on an original methodology, which has integrated criteria used at national level and own criteria (which concerned the sources of mineral waters, the therapeutic mud and their valorisation) shows that some settlements have favourable conditions for the development of tourism, especially the spa (for recovery or maintenance) through the development of spa or wellness centres.

Depending on the scores obtained as a result of the assessment, there were distinguished within Brassov County three areas with tourism development potential with balneary specific: 1. Făgăraş area (including the villages Rodbav / Băile Rodbav, Perşani / Băile Perşani, Grid and Veneția de Jos); 2. Brașov area (including Măieruş, Codlea, Zizin and Târlungeni), and 3. Rupea area (with the localities Rupea, Homorod / Băile Homorod, Mercheașa and Jimbor). They could become in the future important "tourist attraction poles" for the county population as well as for tourists coming from other regions of the country, thus completing the already recognized areas with mountain resorts famous especially for winter sports (e.g. Poiana Brașov, Predeal) or area well-known for rural tourism (Bran-Moieciu). 


\section{REFERENCES}

Berlescu, E., 1971, Staţiunile balneare de-a lungul timpului şi azi, Medicală Publishing House, Bucharest.

Cândea, M., Erdeli, G., Simion, T., Peptenatu, D., 2003, Potenţialul turistic al României şi amenajarea turistică a spaţiului, Universităţii Publishing House, Bucharest.

Ciangă, N., 1998, Turismul din Carpaţii Orientali: studiu de geografie umană, Presa Universitară Clujeană Publishing House, Clujj-Napoca.

Dinculescu, Tr., Berlescu, E., 1963, Balneofizioterapie, manual pentru şcolile tehnice sanitare, Medicală Publishing House, Bucharest.

Dinculescu, Tr., Teleki, N., Berlescu, E., Drăgan, M., Ivănescu, Tr., Sbenghe, T., 1975, Indicaţii şi contraindicații de trimitere la cură balneo-climatică, Medicală Publishing House, Bucharest.

Dumitrescu, A., Bîrsan, M.V., 2015, 'ROCADA: a gridded daily climatic dataset over Romania (1961-2013) for nine meteorological variables', Natural Hazards, vol. 78, no 2, pp. 1045-1063.

Ionac, N., Ciulache, St., 2008, Atlasul bioclimatic al României, Ars Docendi Publishing House, Bucharest.

Mereț, R., 2013, Rodbav baths resort (Braşov County). Therapeutic potential and its exploitation, in Air and Water Components of the Environment Conference Proceedings, pp. 460-467, Presa Universitară Clujană, Publishing House, Cluj-Napoca.

Mereţ, R., 2017, Apele minerale din judeţul Brașov şi valorificarea lor (teză de doctorat), Universitatea din București.

Mereţ, R., Zaharia, L., 2014, Mineral waters at Băile Perşani (Braşov county) and their use, "Water resources and wetlands" Conference Proceedings, pp. 585-562, Transversal Publishing House, Târgovişte.

Mereț, R., Zaharia, L., 2016, Mineral Waters in Rupea City: Physicochemical Features and Use, in Air and Water Components of the Environment Conference Proceedings, pp. 328-337, Casa Cărţii de Ştiinţă Publishing House, Cluj-Napoca.

Mereț, R., Zaharia, L., Grecu, F., 2017, Characteristics and Use of Mineral Waters and Therapeutic Muds from Grid Village Area (Brașov County), in Air and Water Components of the Environment Conference Proceedings, pp. 443-450, Casa Cărţii de Ştiinţă Publishing House, Cluj-Napoca.

Munteanu, C., Dumitraşcu, M., 2011, 'Nămoluri terapeutice', Balneo - Research Journal, vol. 2, no. 3, pp. 12-16.

Teodoreanu, E., Dacoş-Swoboda, M., Ardeleanu, C., Enache, L., 1984, Bioclima staţiunilor bioclimatice din România, Sport-Turism Publishing House, Bucharest.

*** (2000) List of natural reserves (Lista rezervatiilor naturale) declared by the Law No. 5, 2000, Section 3.

*** (2005), Feasibility study on the exploitation, use and protection of mineral water reserves in Băile Rodbav, Brasov County (Studiu de fezabilitate privind exploatarea, valorificarea şi protecţia rezervelor de ape minerale din zăcământul Băile Rodbav, judeţul Brașov), S.C.MINACVA SERV. S.R.L., Bucureşti.

*** (2015), List of historical monuments in Braşov County (Lista monumentelor istorice din judeţul Braşov), Institutul Patrimoniului Naţional.

*** (2016), The methodology for the analysis of the tourist potential of the territory, with Annexes $A$ and $B$ (Metodologia pentru analiza potentialului turistic al teritoriului, $c u$ Anexele A și B, Ministerul Dezvoltării Regionale şi Administraţiei Publice (no. 549 / 25 April 2016) and Ministerul Economiei, Comerţului şi Relaţiilor cu Mediul de Afaceri (no. 518/14 June 2016), published in Monitorul Oficial al României, Partea I, no. 444.14 June 2016.

*** https://es.climate-data.org/. 